Research Paper

\title{
Petrological Characteristics and Nondestructive Deterioration Assessments for Foundation Stones of the Sebyeonggwan Hall in Tongyeong, Korea
}

\author{
Doo Roo Han ${ }^{1}$, Sung Han Kim², Seok Tae Park ${ }^{3}$, Chan Hee Lee ${ }^{3, *}$ \\ ${ }^{1}$ World Heritage Institute Co. Ltd., Gongju, 32574, Korea \\ ${ }^{2}$ Safety and Disaster Prevention Division, National Research Institute of Cultural Heritage, Daejeon, 34122, Korea \\ ${ }^{3}$ Department of Cultural Heritage Conservation Sciences, Kongju National University, Gongju, 32588, Korea \\ *Corresponding author : chanlee@kongju.ac.kr
}

\section{ARTICLE INFORMATION}

Manuscript received 22 February 2021

Received in revised form 3 April 2021

Manuscript accepted 5 April 2021

Available online 28 April 2021

DOI : http://dx.doi.org/10.9719/EEG.2021.54.2.199

\section{Research Highlights}

- The foundation stones in Tongyeong Sebyeonggwan Hall is composed of 50 rock properties.

- Dominant rock types of the stones were used of dacitic lapilli tuffs and andesitic welded tuffs.

- Most of the foundation stones were deteriorated by physical degradations and salt weathering.

\begin{abstract}
The Sebyeonggwan Hall (National Treasure No. 305) is located on the Naval Headquarter of Three Provinces in Tongyeong, and it has partly undergone with several rebuilding, remodeling, repairing and restorations since it's the first establishment in Joseon Dynasty (AD 1605) of ancient Korea. This study focuses on 50 foundation stones that comprise the Sebyeonggwan. These stones are made of six rock types and currently have various shapes of the surface damages. As the foundation stones, the dominant rock type was dacitic lapilli tuffs, and provenance-based interpretation was performed to supply alternative stones for conservation. Most of the provenance rocks for foundation stones showed highly homogeneity with their corresponding stones of petrography, mineralogy and magnetic susceptibility. According to surface deterioration assessments, the most serious damages of the stones were blistering and scaling. The deterioration mechanism was identified through the analysis of inorganic contaminants, and the primary reason is considered salt weathering caused by sea breeze and other combined circumstances. Based on the mechanical durability of the stones, there was no foundation stone that required the replacement of its members attributed to the degradation of the rock properties, but conservation treatment is considered necessary to delay superficial damage. The foundation stones are characterized by a combined outcome of multiple petrological factors that caused physical damage to surfaces and internal defects. Therefore, it's required to diagnosis and monitoring the Sebyeonggwan regularly for long-term preservation.
\end{abstract}

Keywords : Sebyeonggwan Hall, foundation stones, dacitic lapilli tuff, provenance interpretation, salt weathering

Citation: Han, D.R., Kim, S.H., Park, S.T., Lee, C.H. (2021) Petrological Characteristics and Nondestructive Deterioration Assessments for Foundation Stones of the Sebyeonggwan Hall in Tongyeong, Korea. Korea Economic and Environmental Geology, v.54, p.199-212, doi:10.9719/EEG2021.54.2.199.

хJournal homepage: http://www.kseeg.org/main.html

This is an Open Access article distributed under the terms of the Creative Commons Attribution Non-Commercial License (http:/creativecommons.org/ licenses/by-nc/3.0) which permits unrestricted non-commercial use, distribution, and reproduction in any medium, provided original work is properly cited. pISSN 1225-7281; eISSN 2288-7962/(C2021 The KSEEG. Printed by Hanrimwon Publishing Company. All rights reserved. 


\title{
연구논문
}

\section{통영 세병관 초석의 암석학적 특성 및 비파괴 손상평가}

\author{
한두루 ${ }^{1} \cdot$ 김성한 $^{2} \cdot$ 박석태 $^{3} \cdot$ 이찬희 $^{3, *}$ \\ ${ }^{1}$ 주식회사 세계유산연구원 \\ ${ }^{2}$ 국립문화재연구소 안전방재연구실, \\ ${ }^{3}$ 공주대학교 문화재보존과학과 \\ *책임저자 : chanlee@kongju.ac.kr
}

\section{요 약}

세병관(국보 제305호)은 통영 삼도수군통제영에 위치하며, 1605년에 창건한 이래 최근까지 수차례의 중건, 중수, 보수 및 복원 을 거쳤다. 연구대상인 세병관 초석은 모두 50개로 다양한 표면손상이 나타난다. 이 초석은 총 6 개의 암종으로 구성되어 있으 며, 대부분은 석영안산암질 래피리 응회암이다. 보수용 대체석 수급을 위한 산지해석 결과, 대부분의 암석은 초석과 산출상태, 기재적, 광물학적 및 전암대자율 등 암석학적으로 높은 동질성을 갖는 것으로 나타났다. 초석의 손상유형 중에는 표면의 박리 와 박락이 가장 심한 것으로 나타났으며, 무기오염물 분석을 통한 손상메커니즘으로 볼 때 해풍 및 복합적인 환경에 의한 염풍 화가 주된 원인으로 판단된다. 초석의 기계적 내구성으로 보아 현재 물성 저하로 부재의 교체가 필요한 것은 없으나 표면적인 손상을 늦추기 위한 보존처리가 필요할 것으로 보인다. 이 초석은 표면에 발생한 물리적 손상과 내부 결함을 유발하는 암석학 적 요인이 복합적으로 작용하였다. 따라서 세병관의 장기적 보존을 위해서는 주기적인 상태 진단과 모니터링이 요구된다.

주요어 : 세병관, 초석, 석영안산암질 래피리 응회암, 산지해석, 염풍화

\section{1. 서 언}

세병관(국보 제305호)은 경상남도 통영시 세병로 27(문 화동)의 조선시대 삼도수군통제영에 위치한다. 이는 선조 38년(1605)에 제6대 이경준 통제사가 창건하였으며, 고종 32년(1895)에 폐지될 때까지 약 290년 동안 경상, 전라 및 충청 수군의 통제영 본영으로 사용되었다. 또한 매년 봄과 가을에 군사를 훈련하고 경상도와 전라도의 장수들 이 모여 충무공 이순신을 기리던 통제사영과 전패를 모 시는 객사의 기능도 수행하였다(Kim, 2005).

이 세병관은 창건 이후 여러 차례의 중건과 보수공사 를 거쳐 현재의 모습을 유지하고 있으나, 초석에서는 배 치특성과 풍화환경의 노출로 인해 다양한 손상이 나타난 다. 특히 지리 및 입지환경에 따른 해풍의 영향과 치석 의 형태 및 재질특성에 따른 초석 표면의 물리적 손상이 현저하다. 그러나 세병관과 같은 초대형 건축문화재의 구 성요소 중 초석의 중요성에 비해 보존과 안정성 평가를 위한 연구는 상대적으로 미흡한 상태로서, 대상문화재의 성격에 부합하는 암석학적 특성과 산지연구의 필요성이 제기되었다.

따라서 이 연구에서는 세병관 초석의 암종에 따른 재 질특성을 살펴보고 보수용 석재의 수급을 위한 산지를
검토하여 암석학적 기초자료를 구축하였다. 또한 초석 표 면에 나타난 다양한 손상유형을 기록하여 석재의 주요 손상원인을 분석하고 종합적으로 손상도를 평가하였다. 특히 석재표면에서 확인되는 변색 등에 대한 분석을 바 탕으로 손상메커니즘을 규명하고, 비파괴 물성진단을 통 해 부재의 재사용 여부에 가장 주요한 지표인 강도를 파 악하였다. 이 결과는 세병관 초석의 보존 및 보수의 중 요한 자료로 활용할 수 있을 것이다.

\section{2. 현황 및 연구방법}

\section{1. 현 황}

세병관은 정면 9 칸에 측면 5 칸 규모의 팔작지붕으로 건축되었으며, 내부 바닥에는 우물마루를 깔고 중앙 뒷 면 일부를 올려 단을 형성하였다(Fig. 1A). 경사면에 축 조한 세병관은 기단을 설치하여 평탄을 맞추고, 이 기단 위에 초석을 배치하였다. 세병관의 정면과 우측면 및 내 부의 초석은 매끄럽게 가공하여 배치하였으나, 배면과 좌 측면의 초석은 대부분 덤벙주초와 같이 부정형으로 약간 의 다듬질 흔적만 있다(Fig. $1 \mathrm{~B}, 1 \mathrm{C})$.

세병관의 초석은 총 50 개로 구성되어 있으며 6 개의 암 종이 혼재한다. 이 중에서 외부로 노출된 외진주 초석이 

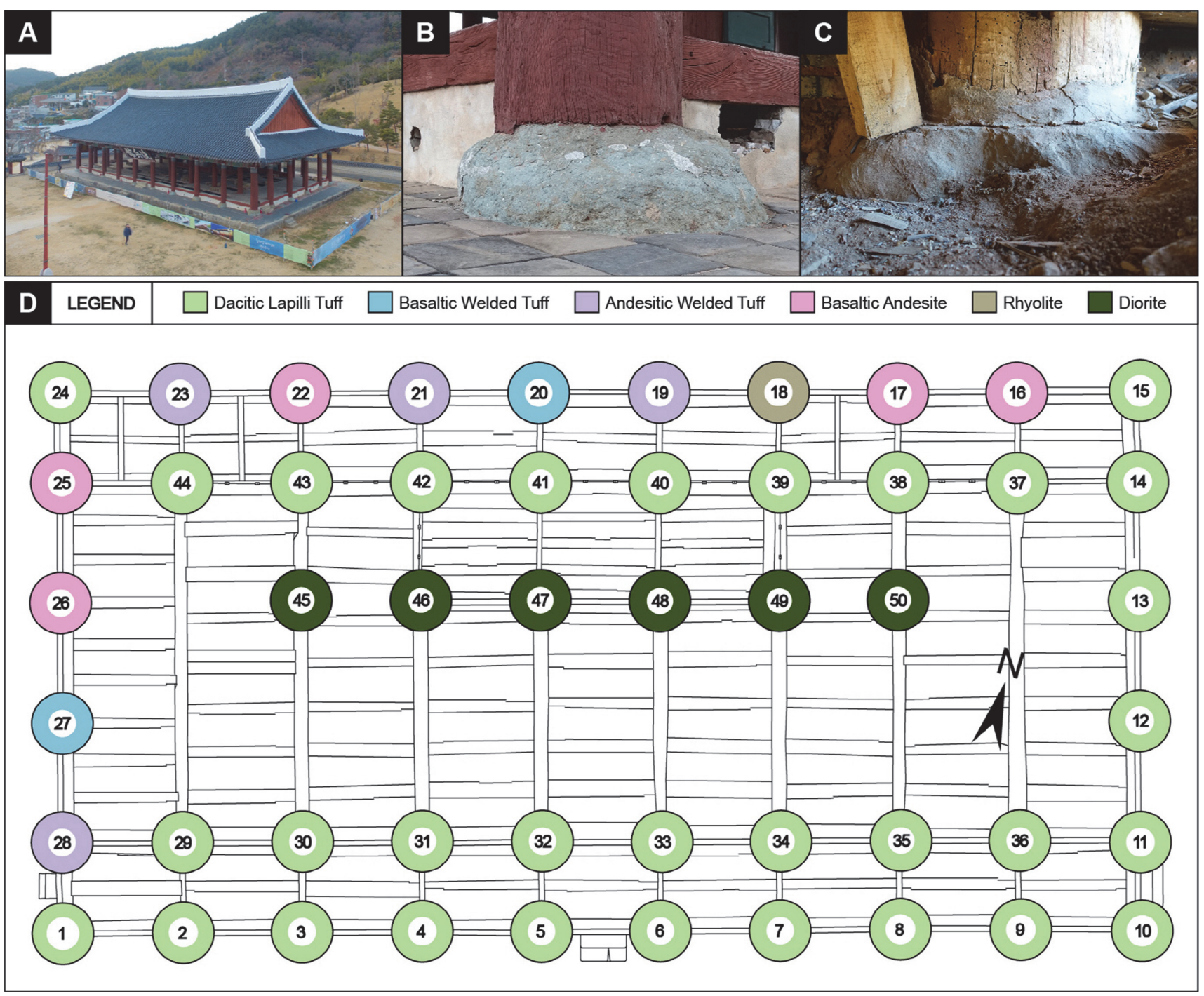

Fig. 1. Current states and distribution of the rock types for foundation stones according to locations in the Sebyeonggwan Hall. (A) Frontal view of the Sebyeonggwan Hall. (B) Outer foundation stones. (C) Inner foundation stones. (D) Rock types showing the schematic floor plan of foundation stones.

28개, 우물마루 밑에 있는 내진주 초석이 22개이다(Fig. 1D). 외진주 초석의 바깥쪽에는 초석과 초석 사이에 약 $125 \mathrm{~mm}$ 두께의 고막이가 설치되어 있고, 내진주 초석은 우물마 루로 노출을 제한하였다.

이 초석은 창건 이후 규모 확대를 수행한 중건과 보수 공사를 거치면서 다양한 암종이 혼재된 것으로 추정된다. 주요 구성암석은 전체 초석 중에서 32 개 $(64 \%)$ 를 차지하 는 석영안산암질 래피리 응회암이다(Fig. 1D). 이 응회암 은 정면과 우측면 및 건물의 모서리 등 주요지점에 위치 하며 일정하게 잘 다듬어진 치석형태가 확인된다. 또한 이 암석은 내진주 초석의 중심부에 조성한 일부 섬록암 을 제외하면 모든 내진주 초석에도 사용되었다.

한편 세병관의 중심부에는 섬록암으로 이루어진 6 개의
내진주 초석이 점유하고 있으며, 서측면과 북측면 외부 로 현무암질 안산암 5개, 안산암질 용결응회암 4개, 현무 암질 용결응회암 2 개, 유문암 1 개가 외진주의 초석으로 활용되었다(Fig. 1D). 이와 같이 대부분 응회암계열의 암 석이 초석으로 사용되었으며, 섬록암을 제외하면 세병관 일대의 지질분포와 매우 유사한 특징을 보인다. 이 중에 서 섬록암 및 유문암으로 조성한 초석은 현대적 가공수 법과 시멘트 다짐의 모습으로 보아 근래의 보수공사에 새롭게 반입된 암석으로 판단된다.

세병관의 원래 초석은 오랜 기간에 걸쳐 인접한 바다 에서 부는 해풍 등의 외부적 환경과 고막이와 우물마루 로 조성된 내부적 환경 등에 영향을 받아 다양한 유형의 손상이 발생하였다. 또한 남동쪽 출입구에 주로 배치된 
석영산암질 래피리 응회암 초석을 비롯하여 신재를 제외 한 모든 초석의 표면에서는 형태적 변형에 따른 안정적 인 하중전달이 우려되는 상황이다. 따라서 이 연구에서 는 모든 초석을 대상으로 재질특성을 분석하고 산지를 해석하였으며, 비파괴 정밀진단을 통해 손상메커니즘과 물리적 안정성을 검토하였다.

\section{2. 연구방법}

이 연구에서는 세병관 초석에 대한 다양한 암종의 암 석학적 특성과 산지해석을 위해 고해상도 사진촬영, 산 출상태, 전암대자율 측정 및 암석광물학적 분석을 수행 하였다. 사진촬영은 SONY 사의 RX100 MK3 모델을 사 용하였고, 초석의 대자율 측정은 $10^{-7} \mathrm{SI}$ 단위의 한계를 가진 ZH Instruments 사의 SM30 대자율기를 이용하였으 며 측정값은 $10^{-3} \mathrm{SI}$ 단위로 표기하였다.

암석별 광물학적 및 조직적 특징을 규명하기 위해 박 편을 제작하고 편광현미경 관찰을 수행하였으며, 사용된 기기는 자동계수기가 장착된 Nikon 사의 Eclipse E600W 편광 및 반사 겸용현미경이다. 아울러 조암광물의 정밀 한 동정을 위해 $\mathrm{X}$-선 회절분석을 수행하였다. 분석에 활 용한 기기는 Rigaku D/Max-IIB이며, 타겟으로 사용한 X선은 $\mathrm{CuK} \alpha$ 에 양극의 가속전압 및 필라멘트의 전류는 각 각 $40 \mathrm{kV}$ 와 $100 \mathrm{~mA}$ 이다. 한편 암석의 지구화학적 정량분 석을 위해 유도결합 플라즈마 분광분석기와 질량분석기 (ICP-AES, ICP-MS) 및 중성자방사화분석기(INAA)를 이 용하였으며, 표준시료와 중복시료를 통해 검증하였다.

또한 초석에 발생한 손상유형을 세분하여 기록하고 위 치 및 분포를 파악하기 위해 획득한 사진자료를 활용하 여 손상지도를 작성하였다. 이는 선행연구를 통해 검증 된 방법(Jo and Lee, 2011)에 따라 수행하였으며, Autodesk 사의 AutoCAD를 이용하여 손상요인별 정량적 평가를 실 시하였다. 일부 육안으로 관찰이 어려운 박리부위에 대
해서는 타진법과 FLIR 사의 T640 적외선열화상 카메라 를 이용하여 정량적인 손상범위를 산출하였다(Jo and Lee, 2014a).

초석의 손상유형 중 표면에 형성된 다양한 오염물에 대 하여 오염종, 생성원인 및 암석특성에 따른 비교를 위해 Oxford 사의 P-XRF(X-MET7500)를 이용하여 토양모드 로 분석하였다. 표면오염물의 미세조직 관찰 및 정성적 인 동정에는 TESKAN 사의 주사전자현미경(MIRA3 LMH) 과 BRUKER 사의 EDS(QUANTAX200) 분석을 병행하 였다. 또한 초음파 측정(Pundit LAB, Proceq)을 통한 방 위별 초음파속도 $2 \mathrm{D}$ 모델링과 풍화도지수 산출을 바탕 으로 초석의 거시적 및 미시적 물성평가를 수행하였다.

\section{3. 결과 및 해석}

\section{1. 암석학적 특성 및 산지해석}

세병관 초석은 석영안산암질 래피리 응회암(32개), 현 무암질 용결응회암(2개), 안산암질 용결응회암(4개), 현무 암질 안산암(5개), 유문암(1개) 및 섬록암(6개)으로 이루 어져 있다(Table 1). 석영안산암질 래피리 응회암은 $1 \mathrm{~mm}$ 이상의 사장석 결정과 암편이 다수 관찰되며, 부분적으 로 미립의 흑운모가 성장해 있다(Fig. 2).

현무암질 용결응회암과 안산암질 용결응회암은 유색 및 무색광물 반정이 공존하며, 광물입자는 대부분 사장 석과 휘석으로 확인되었다(Fig. 2). 현무암질 안산암은 1 $\sim 2 \mathrm{~mm}$ 의 사장석 및 휘석 입자와 사장석 기질로 이루어 져 있고, 유문암은 대부분 $0.1 \mathrm{~mm}$ 내외의 석영으로 구성 되어 있다(Fig. 2). 섬록암은 중조립질로 사장석, 알칼리 장석, 흑운모 및 각섬석이 관찰된다(Fig. 2).

신부재인 섬록암과 유문암 초석을 제외한 주요 구성암 석의 산지해석을 위해 Chang et al.(1983)의 지질도를 바 탕으로 세병관 일대의 지질을 조사하여 인근에서 동종

Table 1. Sample names and rock types of foundation stones and rocks for presumed provenance area in the Sebyeonggwan Hall

\begin{tabular}{|c|c|c|c|}
\hline Sample No. & Rock Type & Location & GPS Coordinates \\
\hline TS-1 & Dacitic Lapilli Tuff & Sebyeonggwan Hall & $\mathrm{N} 34^{\circ} 84^{\prime} 77^{\prime} 4^{\prime \prime}, \mathrm{E} 128^{\circ} 42^{\prime} 31^{\prime} 5^{\prime \prime}$ \\
\hline TS-2 & Basaltic Welded Tuff & Sebyeonggwan Hall & $\mathrm{N} 34^{\circ} 84^{\prime} 77^{\prime} 4^{\prime \prime}, \mathrm{E} 128^{\circ} 42^{\prime} 31^{\prime} 5^{\prime \prime}$ \\
\hline TS-3 & Andesitic Welded Tuff & Sebyeonggwan Hall & $\mathrm{N} 34^{\circ} 84^{\prime} 77^{\prime} 4^{\prime \prime}, \mathrm{E} 128^{\circ} 42^{\prime} 31^{\prime} 5^{\prime \prime}$ \\
\hline TS-4 & Basaltic Andesite & Sebyeonggwan Hall & $\mathrm{N} 34^{\circ} 84^{\prime} 77^{\prime} 4^{\prime \prime}, \mathrm{E} 128^{\circ} 42^{\prime} 31^{\prime} 5^{\prime \prime}$ \\
\hline TS-5 & Rhyolite & Sebyeonggwan Hall & $\mathrm{N} 34^{\circ} 84^{\prime} 77^{\prime} 4^{\prime \prime}$, E128 $42^{\prime} 31^{\prime} 5^{\prime \prime}$ \\
\hline TS-6 & Diorite & Sebyeonggwan Hall & $\mathrm{N} 34^{\circ} 84^{\prime} 77^{\prime} 4^{\prime \prime}, \mathrm{E} 128^{\circ} 42^{\prime} 31^{\prime} 5^{\prime \prime}$ \\
\hline TSS-1 & Dacitic Lapilli Tuff & Hwawonsa Temple & $\mathrm{N} 34^{\circ} 84^{\prime} 64^{\prime} 7^{\prime \prime}, \mathrm{E} 128^{\circ} 40^{\prime} 60^{\prime} 7^{\prime \prime}$ \\
\hline TSS-2 & Dacitic Welded Tuff & Gyeongsang National University & $\mathrm{N} 34^{\circ} 84^{\prime} 90^{\prime} 1^{\prime \prime}, \mathrm{E} 128^{\circ} 42^{\prime} 23^{\prime} 4^{\prime \prime}$ \\
\hline TSS-3 & Andesitic Welded Tuff & Hwawonsa Temple & $\mathrm{N} 34^{\circ} 84^{\prime} 64^{\prime} 7^{\prime \prime}, \mathrm{E} 128^{\circ} 40^{\prime} 60^{\prime} 7^{\prime \prime}$ \\
\hline TSS-4 & Basaltic Andesite & Backside of Sebyeonggwan Hall & $\mathrm{N} 34^{\circ} 83^{\prime} 74^{\prime} 4^{\prime \prime}$, E128 $40^{\prime} 29^{\prime} 4^{\prime \prime}$ \\
\hline
\end{tabular}




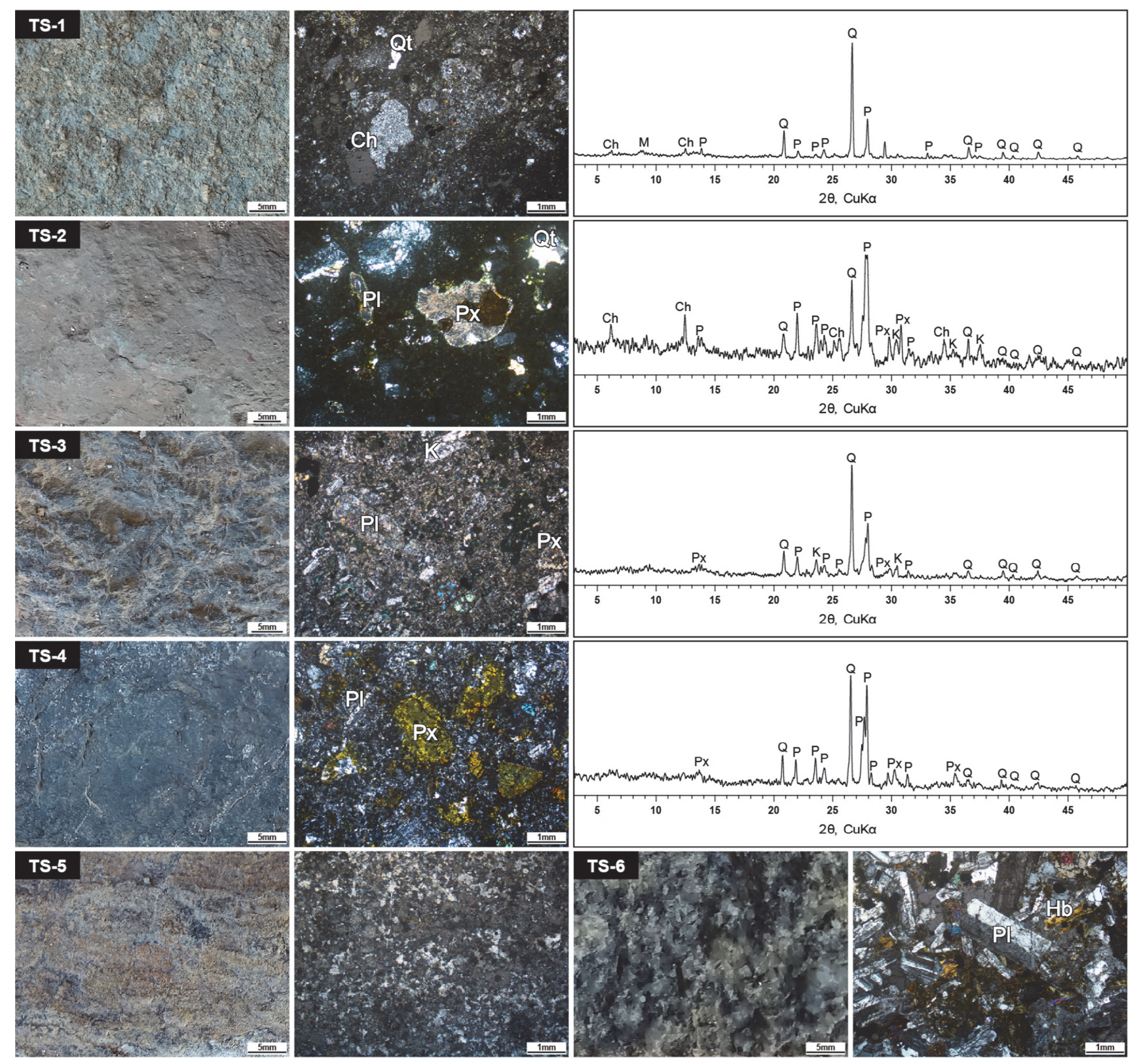

Fig. 2. Results showing the occurrences, polarization microscopy and X-ray powder diffraction analysis of foundation stones in the Sebyeonggwan Hall. Ch; chlorite, M; mica group minerals, P; plagioclase, Q; quartz, K; alkali feldspar, Px; pyroxene, Hb; hornblende. Numbers of the rock samples are the same as those of Table 1.

암석의 존재를 확인하였으며, 이들의 위치와 지리적 좌 표는 Table 1에 제시하였다. 따라서 세병관 일대의 노두 에서 석영안산암질 래피리 응회암과 현무암질 용결응회 암, 안산암질 용결응회암 및 현무암질 안산암의 시료를 획득하였으며, 이를 세병관 초석 시료와 비교 및 분석하 였다(Fig. 3). 이 결과, 석영안산암질 래피리 응회암은 세 병관 초석과 같이 수 $\mathrm{mm}$ 의 암편이 공존하고, 사장석이 길 게 신장된 형태가 확인되었으며, 초석과 같이 담록색의 기질을 보였다(Fig. 3).
현무암질 용결응회암의 경우 암편 및 입자의 크기와 조 직적 특징에 약간의 차이가 있으며, X-선 회절분석으로 는 초석 시료와 달리 휘석과 녹니석은 동정되지 않았다 (Fig. 3). 안산암질 용결응회암은 초석과 산지의 암석 모 두 동일한 광물조성을 보였으며, 암편과 입자를 구성하 는 광물은 사장석과 알칼리 장석이 산출되었다(Fig. 3). 현무암질 안산암은 초석과 산지암석이 광물암석학적으로 매우 유사한 특징을 보였다(Fig. 3).

기재적 및 광물학적 분석 결과, 세병관 초석과 산지암 

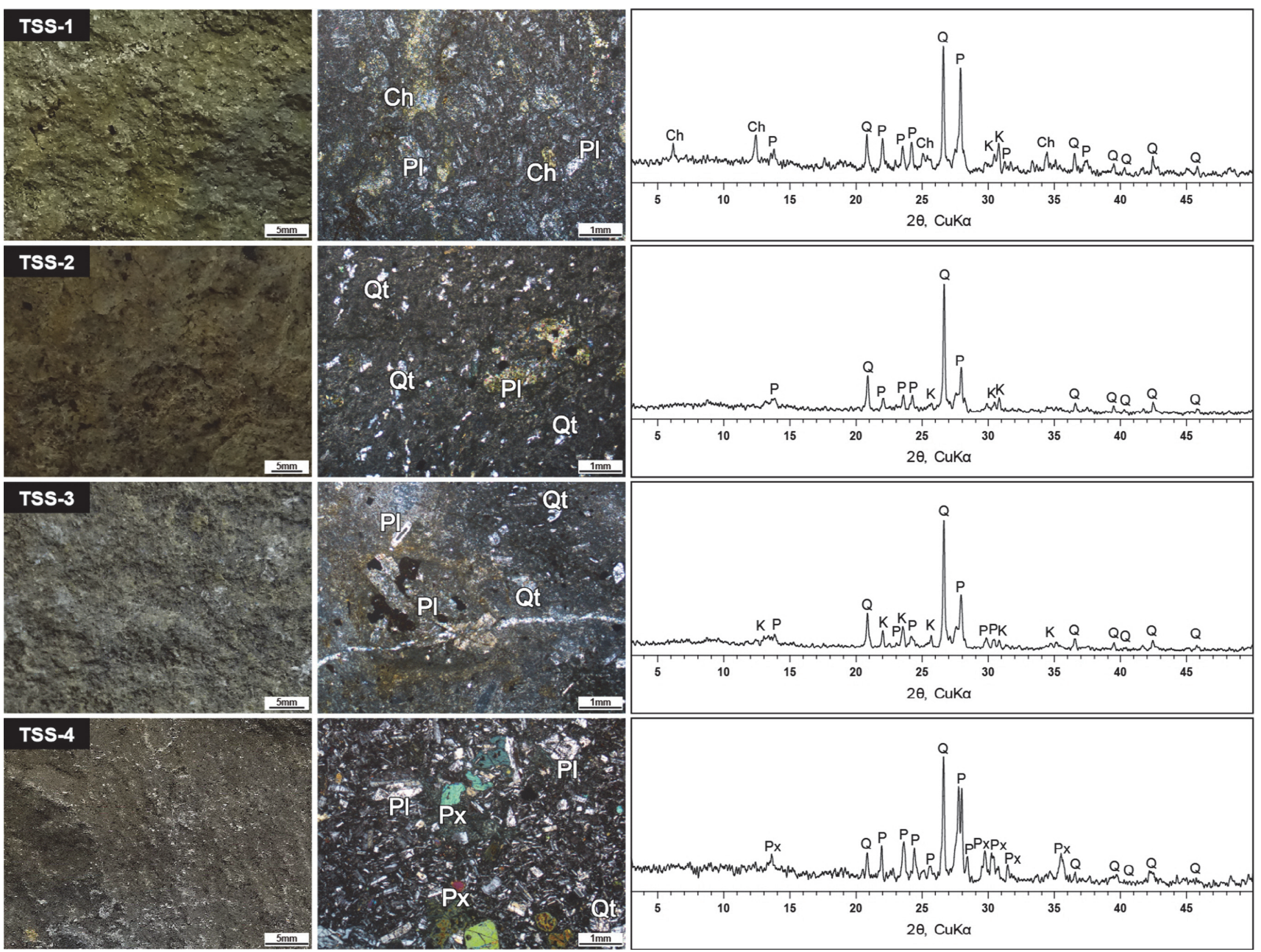

Fig. 3. Results showing the occurrences, polarization microscopy and X-ray powder diffraction analysis of rock samples from the presumed provenance area for foundation stones in the Sebyeonggwan Hall. Ch; chlorite, M; mica group minerals, P; plagioclase, Q; quartz, K; alkali feldspar, Px; pyroxene. Numbers of the rock samples are the same as those of Table 1.

석 시료 중 응회암은 대부분 유사한 암석광물학적 특징 을 갖기도 하지만 부분적인 차이도 있다. 따라서 동질성 규명을 위해 세병관 초석과 산지암석의 전암대자율을 비 교하였다. 전암대자율 분석을 통한 암석의 동질성 규명 은 이미 국내외 석조문화재의 석재산지를 해석하는데 효 과적인 기법으로 문화재 원형복원에 활용되어 온 검증된 연구방법이다(Lee et al., 2007; 2010; Park et al., 2019; Uchida et al., 2007). 이 결과, 응회암계열의 암석들과 현 무암질 안산암은 대부분 매우 유사한 영역에 도시되었다 (Fig. 4).

이 암석의 지구화학적 특성과 동질성을 검토하기 위해 주성분 원소를 활용하여 TAS 삼각도에 도시하였다(Le Maitre et al., 2002). 이 결과, 대부분의 초석과 산지암석 은 동일 종류로 판명되었으나 추정산지에서 현무암질 용 결응회암으로 동정한 암석은 화학분석에서 석영안산암질
용결응회암으로 나타났다. 전체적인 암색과 암상은 거의 일치하였으나 이차적인 변질 등이 영향을 준 것으로 판 단되어 향후 재검토가 필요할 것이다. 또한 육안으로 안 산암질 암석으로 동정한 것이 화학분석에서는 현무암질 안산암 영역에 도시되어 약간의 차이를 보였다(Fig. 5).

한편 이들의 지구화학적 동질성 해석을 위해 주성분, 희토류, 호정 및 불호정원소의 거동변화를 살펴보았다. 이를 위해 일반적인 화성암의 평균 주성분 및 미량원소 함량을 기준(Nockolds, 1954; Govindaraju, 1989; Pearce, 1983; Taylor and McLennan, 1985)으로 표준화하여 진화 경향을 검토하였다(Fig. 6).

이 결과, 현무암질 용결응회암을 제외한 각각의 암석 은 기재적 및 광물학적 특성과 같이 일부 원소의 부화와 결핍을 확인할 수 있으나 전반적으로 유사한 거동특성을 보였다(Fig. 6). 따라서 전반적인 암석 및 지구화학적 특 

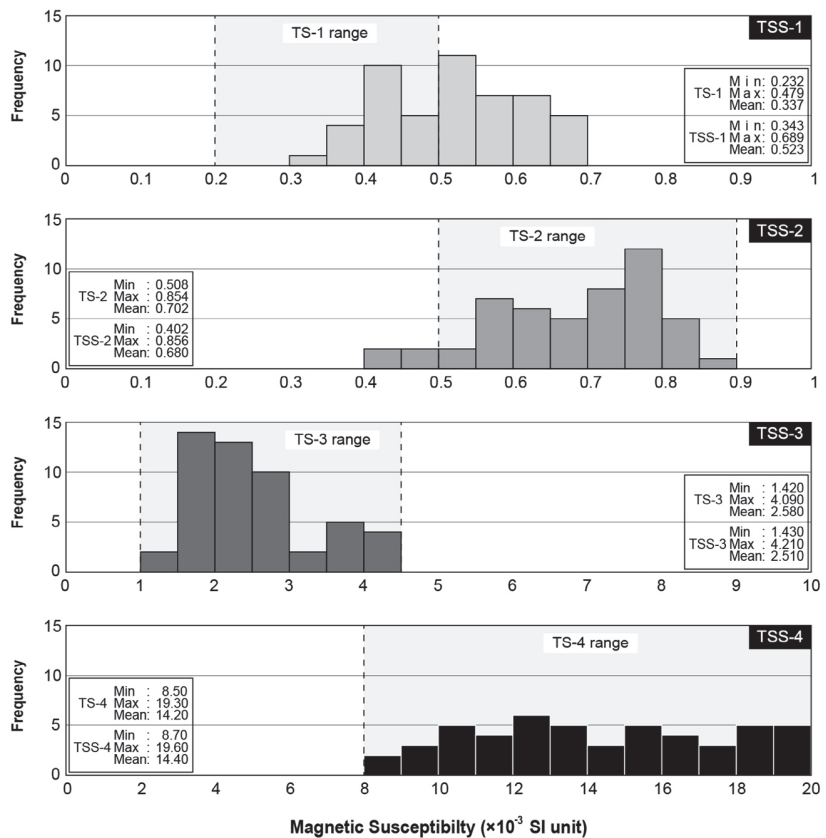

Fig. 4. Magnetic susceptibility of foundation stones in the Sebyeonggwan Hall and the rocks from their presumed provenance. Numbers of the rock samples are the same as those of Table 1.

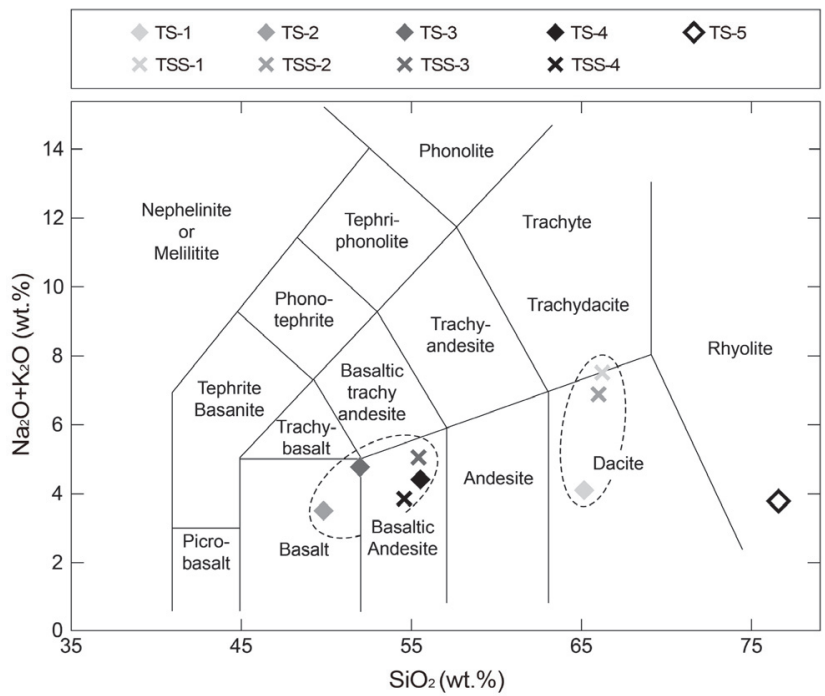

Fig. 5. The TAS diagram (Le Maitre et al., 2002) showing the samples of foundation stones and rocks for presumed provenance area in the Sebyeonggwan Hall.

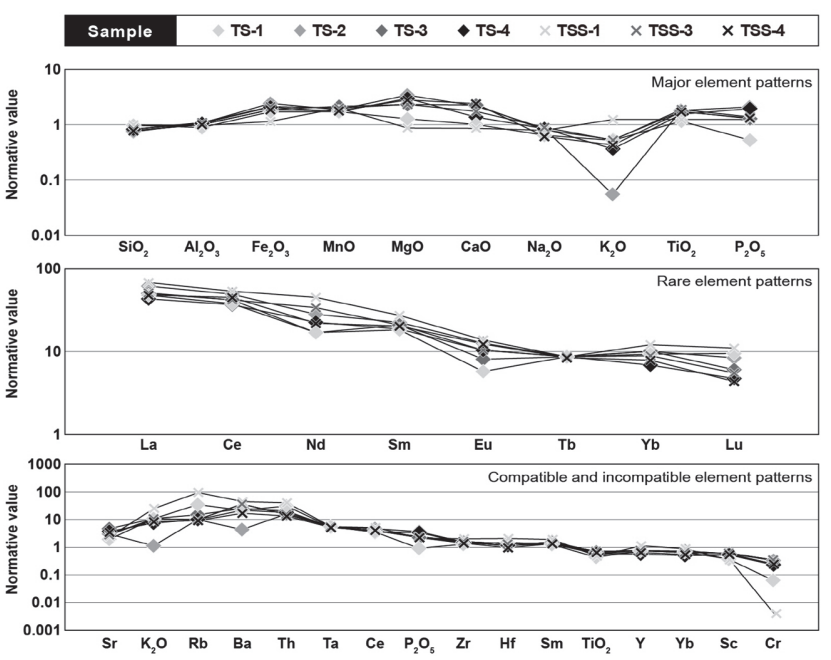

Fig. 6. Variation diagram showing the geochemical behavior of foundation stones in the Sebyeonggwan Hall and the rocks from their presumed provenance. Numbers of the rock samples are the same as those of Table 1.

성으로 보아 세병관 건축에 필요한 초석은 주변의 근거 리 분포하는 석재를 자급자족했을 것으로 해석할 수 있다.

\section{2. 표면손상도 평가}

초석의 손상정도를 암종별로 살펴보면, 석영안산암질 래피리 응회암의 물리적 손상이 가장 심한 것으로 나타 났다. 특히 박리 및 박락이 가장 중요한 손상유형으로 확 인되었다. 초석의 기계적 기능저하의 직접적인 요인인 구 조상 균열은 보이지 않았으나, 박리상 균열을 따라 다수 의 박리와 박락이 관찰되었다(Fig. 7). 화학적 손상비율 은 안산암에서 가장 높았으며, 백화는 석영안산암질 래 피리 응회암 중 내부에 위치한 초석에서 가장 높은 비율 을 보였다. 이차적 보수물질 및 이물질은 모든 암석에 고 르게 분포하고 있다.

따라서 초석의 손상지도를 바탕으로 Jo and Lee(2011) 의 방법에 따라 손상유형별 손상정도를 정량적으로 평가 하였다. 이 결과, 전체 초석에서 균열은 515 개로 기록되 었다. 균열길이의 합은 $34.2 \mathrm{~m}$ 이며 균열지수는 5.0 이다

Table 2. Comprehensive deterioration rate of foundation stones by locations in the Sebyeonggwan Hall

\begin{tabular}{|c|c|c|c|c|c|c|c|c|c|}
\hline \multirow[b]{2}{*}{ Location } & \multicolumn{4}{|l|}{ Index } & \multicolumn{3}{|c|}{ Deterioration Rate (\%) } & \multirow[b]{2}{*}{$\begin{array}{c}\text { Restoration } \\
\text { material }\end{array}$} & \multirow[b]{2}{*}{ Deposit } \\
\hline & Crack & Blistering & Scaling & $\begin{array}{c}\text { Break } \\
\text { out }\end{array}$ & $\begin{array}{c}\text { Black } \\
\text { discolored }\end{array}$ & $\begin{array}{c}\text { Brown } \\
\text { discolored }\end{array}$ & $\begin{array}{c}\text { White } \\
\text { discolored }\end{array}$ & & \\
\hline Outside of outer member & 5.8 & 24.8 & 11.0 & - & 0.9 & 10.2 & 0.0 & 8.4 & 0.9 \\
\hline Inside of outer member & 1.0 & 6.8 & - & - & 0.1 & 8.2 & 0.9 & - & 0.7 \\
\hline Inner member & 2.5 & 8.5 & 1.1 & - & 0.5 & 17.5 & 3.3 & 0.2 & 0.1 \\
\hline Total & 5.0 & 11.4 & 2.8 & - & 0.5 & 14.4 & 2.2 & 1.8 & 0.4 \\
\hline
\end{tabular}




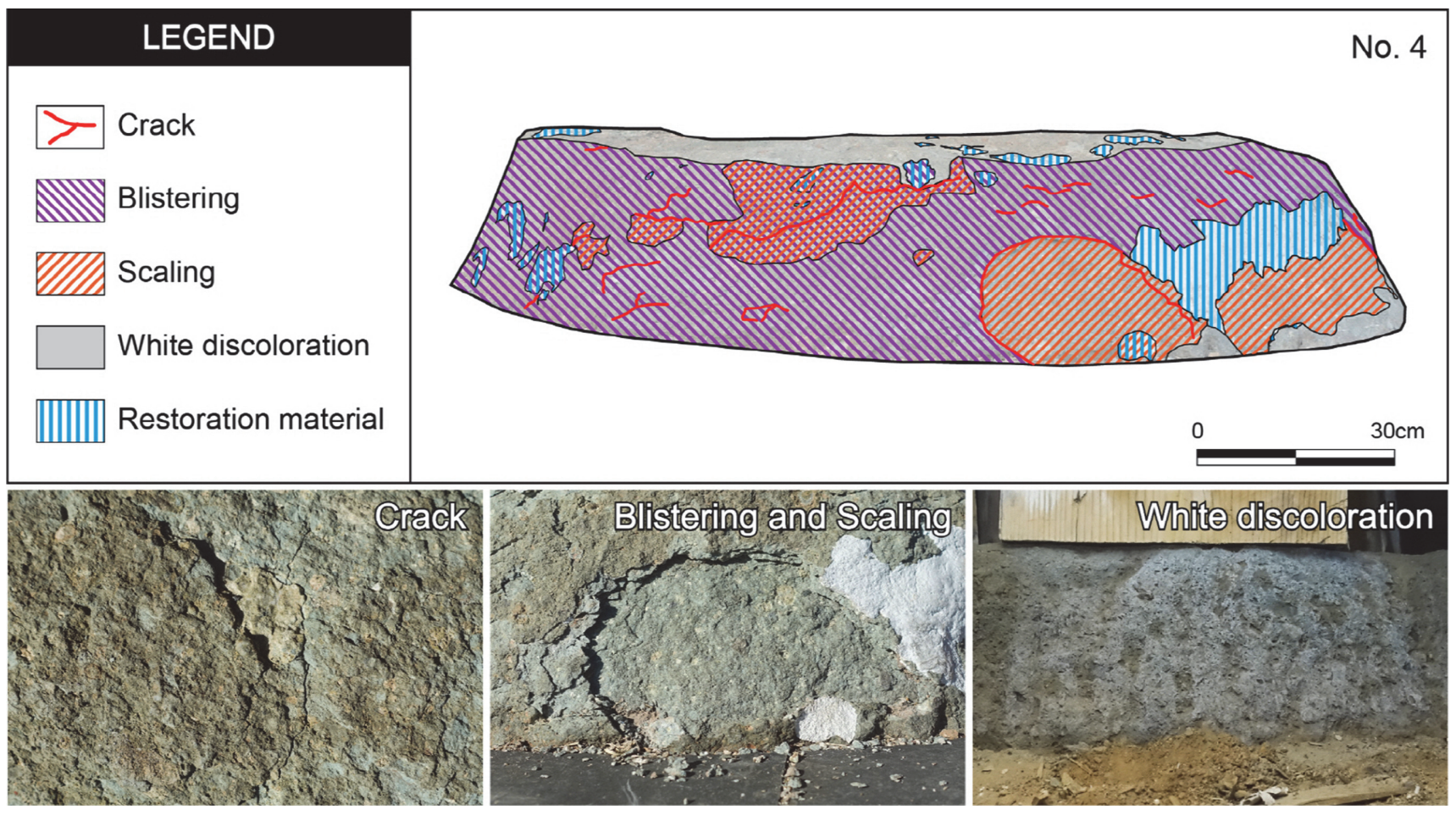

Fig. 7. Representative photographs showing the major damages and the deterioration map of foundation stones in the Sebyeonggwan Hall.

(Table 2). 또한 초석 전체면적의 손상률은 박리 $11.4 \%$, 박락 $2.8 \%$, 흑색변색 $0.5 \%$, 갈색변색 $14.4 \%$, 백색변색 $2.2 \%$, 보수물질 $1.4 \%$, 이물질 $0.4 \%$ 로 물리적 손상에서는 박리가, 화학적 손상에서는 갈색변색이 가장 높은 점유 율을 보였다(Fig. 8).

외진주 초석의 외부면적을 기준으로는 박리 $24.8 \%$, 박 락 $11.0 \%$, 흑색변색 $0.9 \%$, 갈색변색 $10.2 \%$, 보수물질 $8,4 \%$, 이물질 $0,9 \%$ 손상률을 보였다(Table 2). 외부에 노 출된 곳에서 박리와 보수물질의 상대적 점유율이 높았으 며 백색변색이 나타나지 않는다. 외진주 초석 내부의 손 상률은 박리 $6.8 \%$, 흑색변색 $0.1 \%$, 갈색변색 $8.2 \%$, 백색 변색 $0.9 \%$, 이물질 $0.7 \%$ 이며, 박락과 보수물질은 산출되 지 않았다(Table 2). 또한 내진주 초석은 박리 $8.5 \%$, 박 락 $1.1 \%$, 흑색변색 $0.5 \%$, 갈색변색 $17.5 \%$, 백화 $3.3 \%$, 보 수물질 $0.2 \%$ 및 이물질 $0.1 \%$ 의 손상률이 산출되어 갈색 변색의 점유율이 월등히 높음을 보였다(Fig. 8).

또한 초석의 암석종류에 따라 손상도를 평가하고 교차 분석하여 신뢰도를 확보하였다(Table 3). 이 결과, 가장 높은 점유율을 보이는 석영안산암질 래피리 응회암에서 균열지수 5.4로 균열의 밀집도가 가장 높게 산출되었다. 이어 안산암질 용결응회암 0.9 , 현무암질 안산암 0.5 , 현 무암질 용결응회암 0.3 의 순으로 나타났으며, 유문암 및 섬록암에는 균열이 존재하지 않는다(Fig. 8).

석영안산암질 래피리 응회암의 손상률을 보면 박리
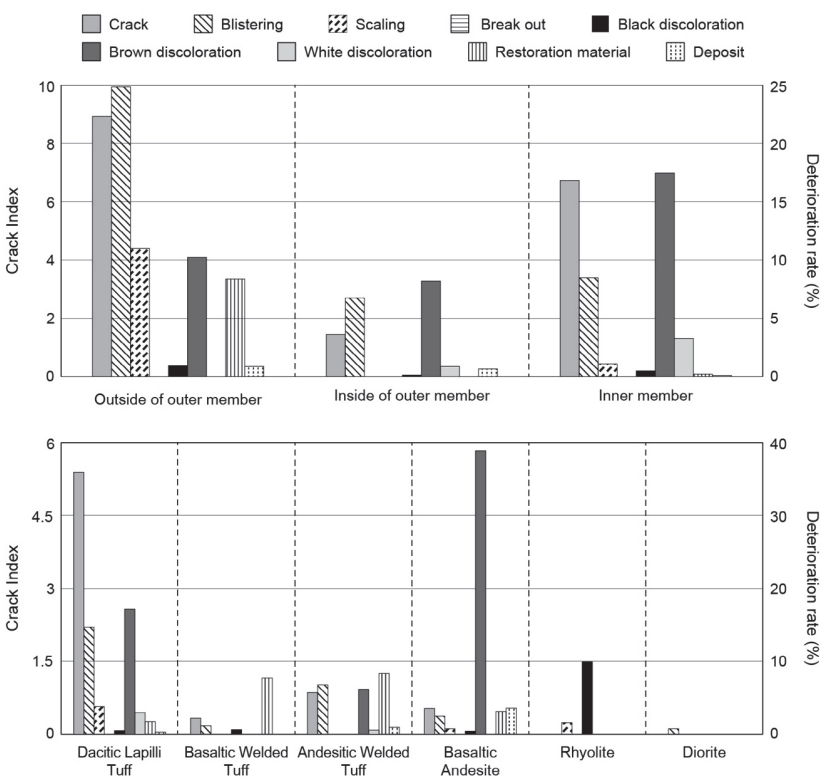

Fig. 8. Diagram showing the total deterioration rates by location and rock type of foundation stones in the Sebyeonggwan Hall.

$14.6 \%$, 박락 $3.7 \%$, 흑색변색 $0.4 \%$, 갈색변색 $17.1 \%$, 백 화 $2.9 \%$, 보수물질 $1.7 \%$, 이물질 $0.3 \%$ 로 산출되었다 (Table 3). 현무암질 및 안산암질 용결응회암은 보수물질 이 각각 $7.7 \%$ 와 $8.3 \%$ 로 상대적으로 높았다(Fig. 8). 현무 암질 안산암에서는 갈색변색(38.9\%)이, 유문암은 흑색변 
Table 3. Comprehensive deterioration rate of foundation stones by rock types in the Sebyeonggwan Hall

\begin{tabular}{|c|c|c|c|c|c|c|c|c|c|}
\hline \multirow[b]{2}{*}{ Rock Type } & \multirow{2}{*}{$\begin{array}{l}\text { Index } \\
\text { Crack }\end{array}$} & \multicolumn{8}{|c|}{ Deterioration Rate (\%) } \\
\hline & & Blistering & Scaling & $\begin{array}{c}\text { Break } \\
\text { out }\end{array}$ & $\begin{array}{c}\text { Black } \\
\text { discolored }\end{array}$ & $\begin{array}{c}\text { Brown } \\
\text { discolored }\end{array}$ & $\begin{array}{c}\text { White } \\
\text { discolored }\end{array}$ & $\begin{array}{c}\text { Restoration } \\
\text { material }\end{array}$ & Deposit \\
\hline Dacitic Lapilli Tuff & 5.4 & 14.6 & 3.7 & - & 0.4 & 17.1 & 2.9 & 1.7 & 0.3 \\
\hline Basaltic Welded tuff & 0.3 & 1.1 & - & - & 0.6 & - & - & 7.7 & - \\
\hline Andesitic Welded tuff & 0.9 & 6.7 & - & - & - & 6.1 & 0.5 & 8.3 & 0.9 \\
\hline Basaltic Andesite & 0.5 & 2.4 & 0.7 & 0.1 & 0.4 & 38.9 & - & 3.1 & 3.6 \\
\hline Rhyolite & - & - & 1.6 & - & 9.9 & - & - & - & - \\
\hline Diorite & - & 0.7 & - & - & - & - & - & - & - \\
\hline
\end{tabular}
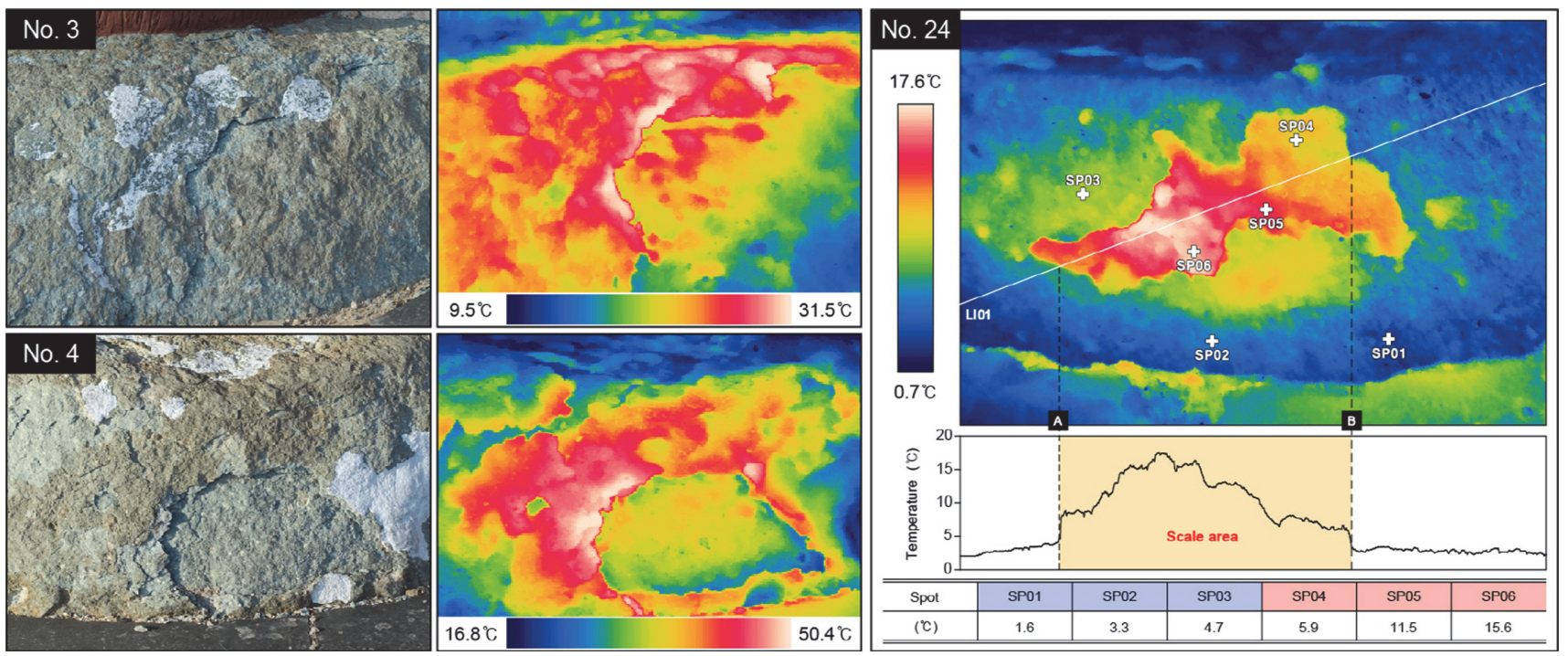

Fig. 9. Photographs showing the detection of blistering zone through the infrared thermal images and temperatures of foundation stones in the Sebyeonggwan Hall.

색(9.9\%)이 주요 손상유형으로 분류되었다(Fig. 8). 섬록 암은 박리에 의한 손상 $(0.7 \%)$ 을 제외하면 상당히 건전한 상태를 보였다.

세병관 초석에서 중요한 손상유형으로 나타나는 박리 및 박락은 염의 결정압에 따른 광물 간의 결속력 저하가 원인으로 판단된다(Fig. 7). 염에 의한 손상률은 외부와 내부 등 환경적 요인이 기여한 것으로 해석할 수 있다 (Fig. 9). 따라서 이 연구에서는 주요 손상유형인 박리의 정량적인 면적을 평가하고자 Fig. 9와 같이 적외선 열화 상 촬영을 통한 온도분석법을 이용하여 박리면적을 검출 하였고, 이를 손상지도에 적용하였다.

\section{3. 무기오염물 분석}

세병관 초석에서 가장 심한 손상유형은 박리 및 박락 으로, 이들은 암석학적 특성과 함께 무기오염물에 따른 화학적 작용이 기여한 것으로 해석된다. 따라서 초석 표 면에 다양한 변색현상을 일으키는 무기오염물의 생성메
Table 4. Results on element contents (ppm) using P-XRF for surface contaminants of foundation stones in the Sebyeonggwan Hall

\begin{tabular}{ccccc}
\hline Classification & $\mathrm{Ca}$ & $\mathrm{Ti}$ & $\mathrm{Mn}$ & $\mathrm{Fe}$ \\
\hline Fresh spot & 32,866 & 3,835 & 806 & 40,128 \\
Brown discolored & 35,366 & 5,667 & 1,457 & 61,814 \\
Black discolored & 16,808 & 3,797 & 23,307 & 26,317 \\
Restoration material & 57,836 & 5,210 & 1,930 & 23,012 \\
Deposit & 188,850 & 2,890 & 713 & 23,127 \\
\hline
\end{tabular}

커니즘 규명을 위해 분석을 수행하였다. 먼저 P-XRF를 활용하여 갈색 및 흑색변색, 보수물질과 이물질을 대상 으로 3회씩 분석하여 평균값을 산출하였다(Table 4). 또 한 신선한 부분에 대한 분석도 병행하여 오염정도 판단 의 기준으로 삼았다.

각 분석지점에 대한 $\mathrm{Ca}, \mathrm{Ti}, \mathrm{Mn}$ 및 $\mathrm{Fe}$ 의 함량 분석 결 과, 보수물질과 이물질에서 칼슘 함량이 $57,836 \mathrm{ppm}$ 과 
$188,850 \mathrm{ppm}$ 으로 신선부에 비해 월등히 높게 검출되었다 (Fig. 10). 이 보수물질과 이물질은 각각 석재용 수지와 고막이용 강회의 칼슘 성분이 검출된 것으로 판단된다. 한편 티타늄은 거의 비슷한 함량으로 변별력을 갖지 못 했다(Fig. 10).

흑색변색 지점에서는 망간이 $23,307 \mathrm{ppm}$ 검출되어 다 른 지점에 비해 월등히 높은 함량을 보였다(Fig. 10). 따 라서 흑색변색은 비정질의 망간산화물에 의한 변색작용 으로 해석할 수 있다. 또한 철은 $61,814 \mathrm{ppm}$ 으로 갈색변 색이 신선부에 비해 매우 높은 함량을 나타냈다(Fig. 10). 이 갈색변색은 조암광물의 철 성분이 외부로 용출되어 나온 산화물질로 해석되며, 석조문화재에 나타나는 대표 적인 화학적 풍화산물로 보인다.

초석 중에서 매우 높은 박리 및 박락현상을 겪고 있는 외진주의 외부는 해풍에 의한 염 풍화작용을 의심할 수 있으며, 내부에서는 결정화를 이룬 백색변색이 나타난다.
이와 같은 염 결정은 조암광물의 입자간 조직을 느슨하 게 만들어 입상분해를 촉진시키며, 암석의 표면을 용해 하여 변색을 유발시키는 등 다양한 선행연구에서도 보고

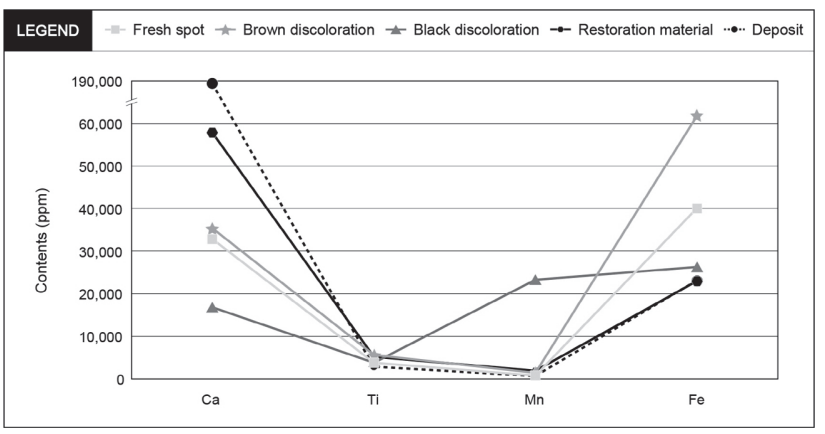

Fig. 10. Diagrams showing the mean contents of $\mathrm{Ca}, \mathrm{Ti}, \mathrm{Mn}$ and $\mathrm{Fe}$ on the surface contaminants of foundation stones in the Sebyeonggwan Hall.

Table 5. Results on element contents (wt.\%) using SEM-EDS for surface contaminants of foundation stones in the Sebyeonggwan Hall

\begin{tabular}{cccccccccccccc}
\hline No. & $\mathrm{Si}$ & $\mathrm{Al}$ & $\mathrm{Ti}$ & $\mathrm{Mn}$ & $\mathrm{Ca}$ & $\mathrm{Na}$ & $\mathrm{Mg}$ & $\mathrm{Fe}$ & $\mathrm{K}$ & $\mathrm{Cl}$ & $\mathrm{S}$ & $\mathrm{C}$ & $\mathrm{O}$ \\
\hline 1 & 11.70 & 6.11 & 0.31 & - & 5.65 & 3.56 & 1.21 & 2.42 & 1.01 & 1.16 & 1.76 & 13.30 & 51.81 \\
2 & 10.98 & 6.02 & 0.23 & - & 4.33 & 4.83 & 1.14 & 1.66 & 0.61 & 1.24 & 2.29 & 16.21 & 50.46 \\
\hline 3 & 6.39 & 5.15 & 0.94 & 13.96 & 6.79 & - & 0.39 & 5.33 & 0.92 & 0.38 & 0.37 & 8.59 & 50.79 \\
\hline 4 & 3.42 & 1.12 & - & - & 29.40 & 0.56 & 2.02 & - & - & 0.21 & 0.56 & 20.23 & 42.48 \\
5 & 2.10 & 1.53 & - & - & 15.14 & - & - & 0.28 & 0.62 & - & 10.73 & 4.45 & 65.15 \\
\hline 6 & 15.55 & 0.91 & - & - & 1.54 & - & 11.83 & 0.37 & - & 0.20 & - & 23.40 & 46.20 \\
\hline
\end{tabular}

Numbers are the same as those of Figure 11.
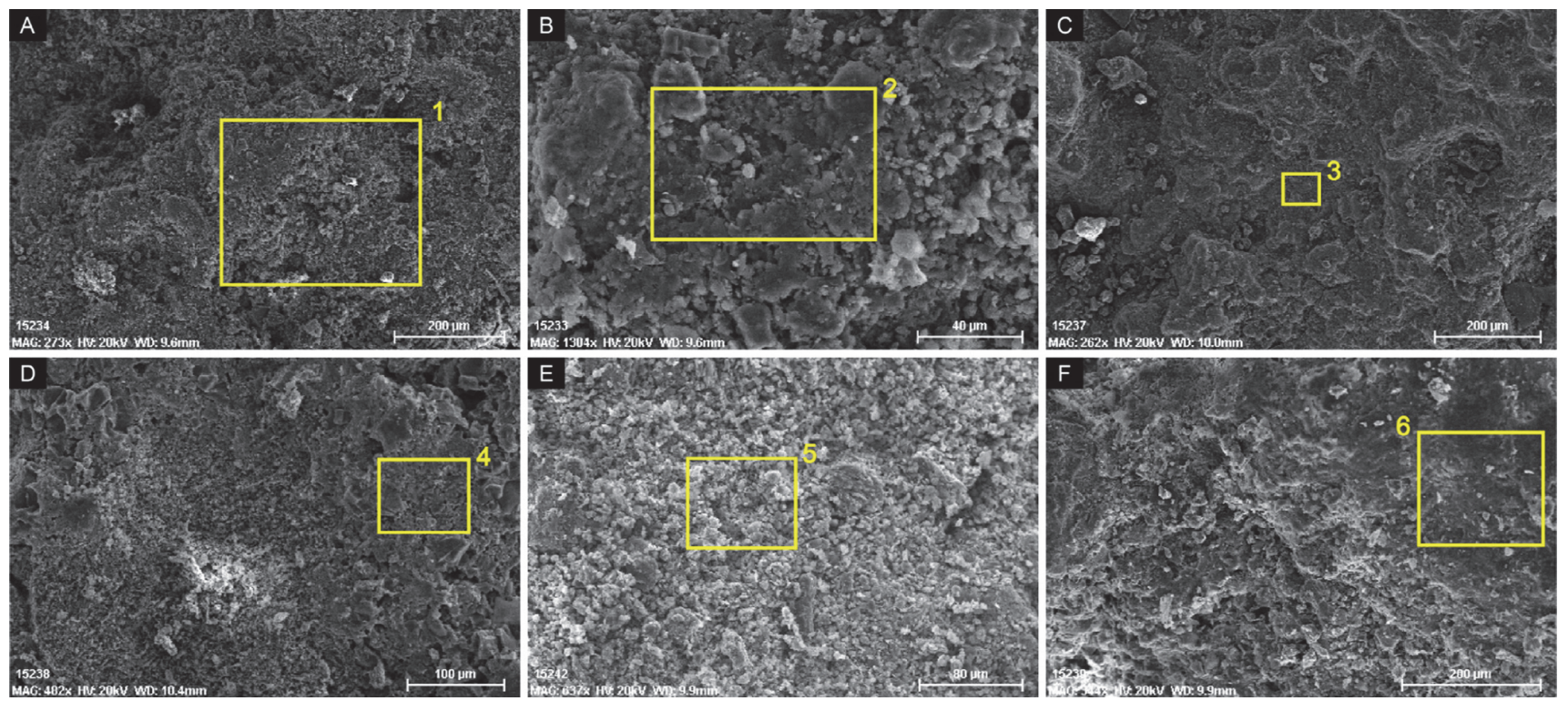

Fig. 11. Microphotographs and spots showing the SEM-EDS analysis for the surface contaminants on foundation stones in the Sebyeonggwan Hall. (A, B) Samples with brown discoloration through the external surface area of dacitic lapilli tuff. (C) Samples of black discoloration. (D) Samples of foreign substances of the Gomagi. (E) Samples with white discoloration in the internal surface area of dacitic lapilli tuff. (F) Samples of repairing materials. 
된 바 있다(Min et al., 2003; Cho et al., 2012; Cho and Lee, 2020).

따라서 초석의 무기오염물에 의한 손상메커니즘을 검 토하기 위해 주사전자현미경 관찰 및 $\mathrm{EDS}$ 분석을 수행 하였다(Table 5). 분석을 위해 외진주의 외부(Fig. 11A, 11B), 흑색변색(Fig. 11C), 고막이(Fig. 9D)와 염결정 (Fig. 11E) 및 보수물질(Fig. 11F) 등에서 극미량 시료를 수습하였다. 이 결과, 외진주 초석 외부시료에서 $\mathrm{Na}$ 과 $\mathrm{Cl}$ 가 상대적으로 높게 검출되었다. 이는 세병관이 바다와 인접해 있는 환경이므로 해풍에 의한 염의 검출로 판단 된다. 흑색변색부에서는 망간이 $13.96 \mathrm{wt} . \%$ 로 검출되어 앞 의 결과와 같이 비정질 망간산화물이 원인임을 알 수 있 다(Table 5).

고막이와 내부에 형성된 염화물에서는 칼슘이 29.40wt.\% 와 $15.14 w t . \%$ 로 검출되어 고막이 조성에 소석회 $\left(\mathrm{Ca}(\mathrm{OH})_{2}\right)$ 가 사용되었을 것으로 추정되며, 백색변색은 대표적인 염 결정형태 중 하나인 석고(gypsum; $\mathrm{CaSO}_{4} \cdot 2 \mathrm{H}_{2} \mathrm{O}$ )로 판단 된다(Table 5). 한편 보수물질에서는 $\mathrm{Mg}$ 의 함량이 높게 검출되었는데(Table 5), 이는 보수물질을 제작할 때 첨가 제로 사용한 활석이 양향을 준 것으로 해석할 수 있다.

\section{4. 초음파 물성진단}

대형건축물의 초석이 상부가구의 하중을 안정적으로 받아 유지하기 위해서는 기계적인 물성이 확보되어야 한 다. 세병관은 매우 큰 규모의 건축문화재로서 초석의 물 성이 낮을 경우 변형의 위험에 노출될 수 있다. 초음파 속도 측정을 이용한 석조문화재의 물성평가는 다수의 연 구자에 의해 표준화된 기법이 정리되었고(Lee et al., 2009; Jo and Lee, 2014b; 2015), 최근에는 석조문화재를 포함 한 다양한 유형의 문화재에서도 널리 활용되고 있다.

따라서 초음파속도를 적용하여 세병관 초석에 대한 건 축부재로서의 성능을 검토하였다. 초음파측정은 이미 잘 알려진 간접측정법과 엘라스토머 커버를 이용하였다( $\mathrm{Jo}_{\mathrm{O}}$ and Lee, 2014b; 2015; Lee and Jo, 2017). 이 연구에서는 모든 초석별로 8 방위를 측정하고 이를 모식도에 도시하 여 경향성을 분석하였다(Fig. 12).

암석의 종류에 따른 보정계수는 응회암 1.48 , 안산암 1.50 , 유문암질암 1.62 및 섬록암 1.62를 적용하였다(Lee and Jo, 2017). 또한 개별 초석에 대한 평균 초음파속도 를 바탕으로 풍화도지수를 산출하고 풍화등급을 산정하 였으며, 암석별 풍화도지수를 통해 세병관 초석의 물성

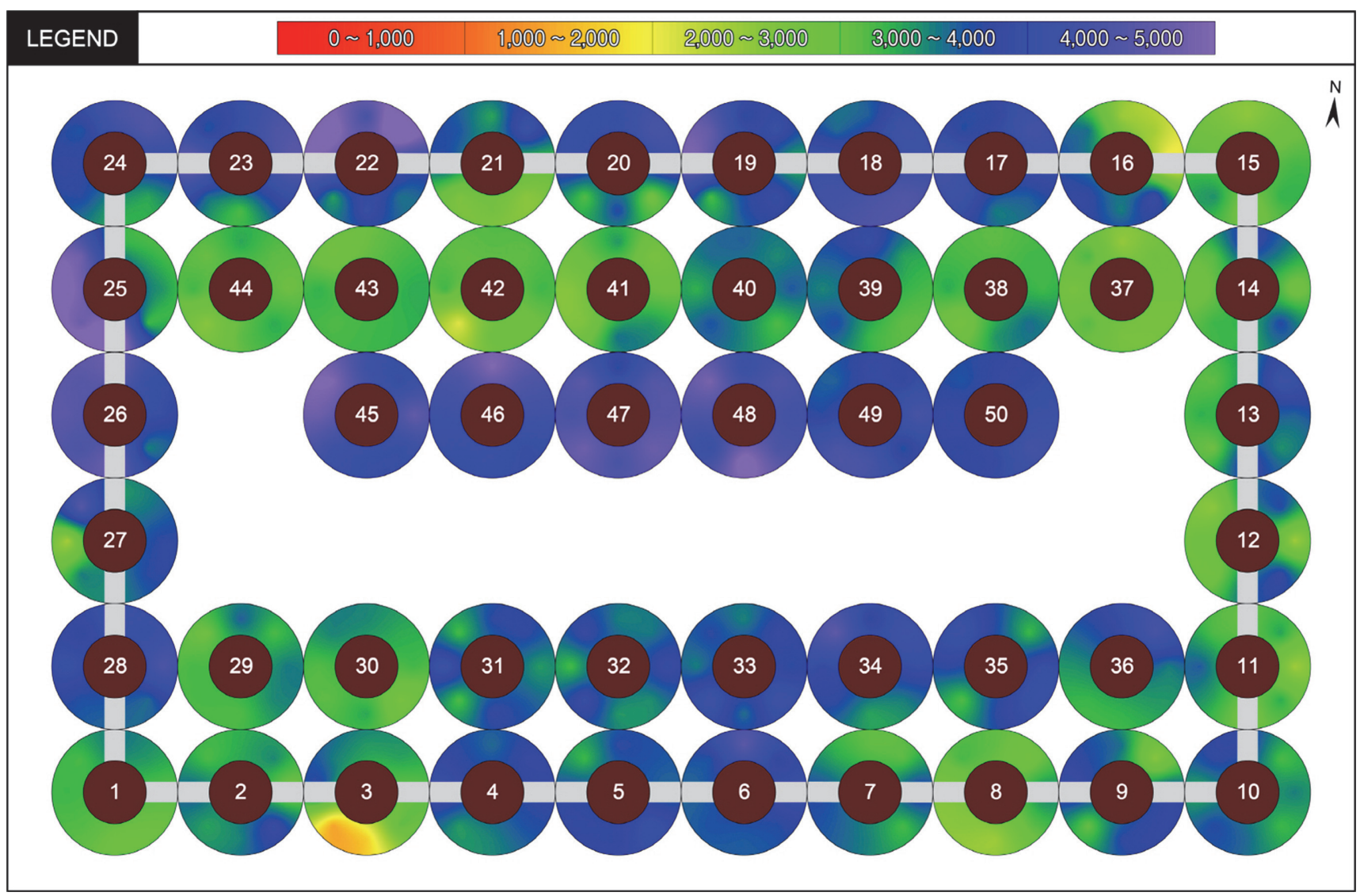

Fig. 12. Result showing the $2 \mathrm{D}$ modeling by ultrasonic velocity of foundation stones in the Sebyeonggwan Hall. Numbers of the rocks are the same as those of Figure 1D. 
Table 6. Summary on ultrasonic velocity of foundation stones in the Sebyeonggwan Hall

\begin{tabular}{|c|c|c|c|c|c|}
\hline \multirow{2}{*}{ Classification } & \multicolumn{3}{|c|}{ Direct Ultrasonic Velocity $(\mathrm{m} / \mathrm{s})$} & \multirow{2}{*}{$\begin{array}{c}\text { Weathering } \\
\text { Coefficient }(\mathrm{K})\end{array}$} & \multirow{2}{*}{ Weathering Grade } \\
\hline & Max & Min & Mean & & \\
\hline Dacitic Lapilli Tuff & 3,880 & 2,838 & 3,385 & 0.32 & MW \\
\hline Basaltic Welded Tuff & 3,786 & 3,731 & 3,758 & 0.25 & MW \\
\hline Andesitic Welded Tuff & 4,008 & 3,233 & 3,767 & 0.25 & MW \\
\hline Basaltic Andesite & 4,362 & 3,141 & 3,990 & 0.20 & MW \\
\hline Rhyolite & - & - & 4,112 & 0.18 & SW \\
\hline Diorite & 4,480 & 3,914 & 4,248 & 0.15 & SW \\
\hline
\end{tabular}

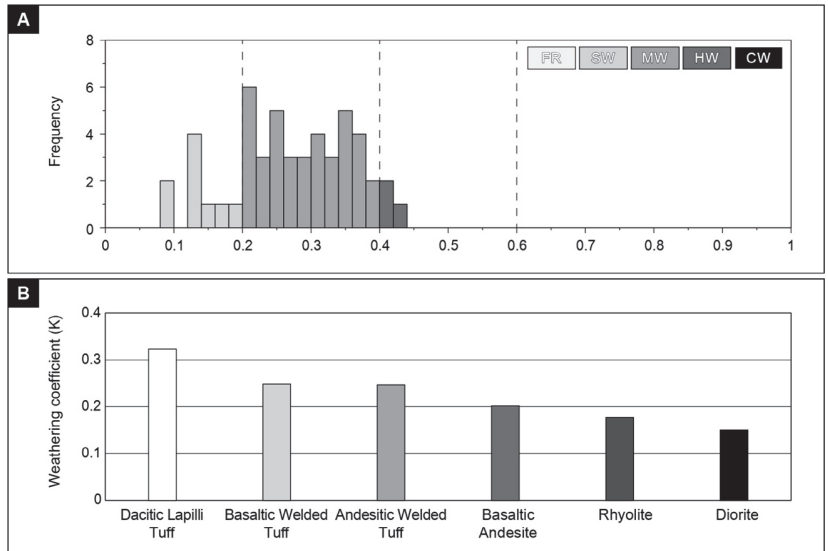

Fig. 13. Distribution diagrams showing the weathering grades and graph on the weathering index of each rock types according to ultrasonic velocity of foundation stones in the Sebyeonggwan Hall. FR; fresh, SW; slightly weathered, MW; moderately weathered, HW; highly weathered, CW; completely weathered

을 진단하였다(Table 6, Fig. 13).

초음파속도 $2 \mathrm{D}$ 모델링 결과, 세병관 초석은 전체적으 로 $3,000 \mathrm{~m} / \mathrm{s}$ 이상의 양호한 물성을 보였다(Fig. 12). 그러 나 일부 초석의 특정 방위에서는 상대적으로 취약한 물 성을 보이기도 하는데, 이는 초석 표면에 발생한 균열 및 박리 등 물리적 손상이 영향을 미친 것으로 판단된다. 실 제로 이와 같이 물리적 손상이 높은 점유율을 보인 초석 에서 초음파속도가 낮게 나타나는 경향이 있다.

특히 초석 3은 남서쪽에서 초음파속도가 $1,416 \mathrm{~m} / \mathrm{s}$ 로서 가장 낮았다. 이 초석의 표면은 전면에 걸쳐 박리가 발 생하면서 층상구조를 갖는 것으로 확인되었고, 박리층이 두꺼워 초음파 신호가 미약하게 도달하는 것으로 나타났 다(Fig. 12). 한편 물리적 손상은 외진주 초석의 외부에 서 높게 나타났으나, 초음파속도는 오히려 외진주 초석 의 내부에서 내진주 초석보다 높게 나타나기도 하였다. 이는 측정지점에 발생한 박리의 깊이가 얕고 육안으로 확인되지 않는 내부 결함의 영향이 더 크게 작용한 것으
로 판단된다.

한편 Iliev(1966)가 제시한 신선한 암석과 풍화된 암석 의 초음파 속도 변화비율에 기초하여 풍화단계별로 풍화 도지수(K)와 등급을 검토하였다(Table 6). 이 결과, 세병 관 초석의 풍화정도는 전반적으로 $2 \sim 3$ 등급에 해당하는 양호한 물성을 보였으며 3 개의 초석 $(8,37,42)$ 이 4 등급 으로 확인되었다. 4 등급에 해당하는 초석도 평균 초음파 속도와 풍화도지수는 각각 $2,915 \mathrm{~m} / \mathrm{s}(0.42), 2,838 \mathrm{~m} / \mathrm{s}(0.43)$ 및 $2,950 \mathrm{~m} / \mathrm{s}(0.41)$ 로 나타나면서 3 등급 물성과 큰 차이를 보이지는 않았다(Fig. 13).

이를 암석의 종류에 따라 구분하여 물성을 검토한 결 과, 풍화도지수와 물성등급은 Table 1의 시료번호 순서대 로 0.32 (3등급; $\mathrm{MW}$ ), 0.25 (3등급; $\mathrm{MW}$ ), 0.25 (3등급; $\mathrm{MW}$ ), 0.20 (3등급; MW), $0.18(2$ 등급; SW) 및 $0.15(2$ 등급; SW) 로 나타났다. 따라서 근래에 교체한 신석재로 판단되는 유문암과 섬록암의 물성이 상대적으로 높은 것으로 평가 되었다(Fig. 13).

\section{4. 보존과학적 고찰}

통영 세병관 초석은 6 개의 암종으로 구성되어 있으며, 암석의 성질 및 건축물의 특성과 주변 환경의 영향을 받 아 다양한 손상유형이 나타난다. 또한 여러 차례의 중수 와 보수 및 피로하중 등도 중요한 요인으로 작용했을 것 이다. 손상도 평가 결과, 가장 현저한 손상유형은 박리 및 박락으로 초석의 내구성에 직접적인 영향을 미치지는 않지만 장기적으로 초석을 구성하는 암석의 물성을 저하 시키는 요인으로 발달할 가능성이 높다. 따라서 이에 대 한 근본적인 원인을 규명하고 체계적인 관리 및 제어를 위한 연구가 필요한 상태였다.

초음파 물성진단 결과, 초석의 기계적 내구성에 심각 한 문제가 있는 초석은 검출되지 않았다. 따라서 시급성 을 다투는 부재의 교체는 없을 것으로 판단되나, 초석의 형태나 암종 및 재질특성을 같이 고려해야 할 것이다. 전 
체적인 손상정도로 볼 때 초석의 우점 암석인 석영안산 암질 래피리 응회암에 발달한 박리와 박락이 특히 외부 에서 많이 나타난다. 이는 암석의 특성과 함께 인접한 바 다에서 불어오는 해풍에 의한 염의 결정화작용이 중요 인자로 판단된다.

이러한 환경조건은 단순한 염화나트륨 $(\mathrm{NaCl})$ 의 형태뿐 만 아니라 세병관에 사용된 다량의 강회 성분과 결합하 여 염화칼슘 $\left(\mathrm{CaCl}_{2}\right)$ 및 석고 $\left(\mathrm{CaSO}_{4} \cdot 2 \mathrm{H}_{2} \mathrm{O}\right)$ 등 다양한 염 결정을 생성하였다. 이는 물과 반응하면서 부피팽창을 통 한 광물 간의 결합력을 저하시키는 직접적인 원인이 된 다. 따라서 화학적 풍화가 가속되는 환경에서는 다양한 형태의 물리적 손상이 동반된다. 이 세병관 초석에서는 박리 및 박락의 형태로 나타나고 있으며 응회암의 재질 특성과 결합하여 다소 복잡한 손상메커니즘을 갖는 것으 로 보인다.

이를 제어하기 위해서는 초석의 보수와 교체에 타당성 을 입증할 수 있는 객관적인 평가기준이 논의되어야 한 다. 그러나 교체 이전에 암석의 기계적인 물성저하와 속 도를 늦추는 보존처리가 필요한 것으로 판단된다. 또한 주변 환경에 따른 풍화가 가속되어 향후 초석이 부재로 서의 내구성이 저하되었을 경우, 부재의 교체가 검토될 수도 있어 대체부재의 선정에 필요한 석재의 산지해석을 수행하였다.

이 결과, 세병관 일대의 지질에서 매우 유사한 동종의 암석을 확보할 수 있으며(Chang et al., 1983), 전체적인 암상과 산출상태, 전암대자율 및 지구화학적 거동특성 등 동질성이 높은 분석 결과를 획득하였다. 그러나 화산암 은 단일 노두에서도 암색과 암석학적 다양성이 높아 실 제 적용에는 면밀한 조사와 검토가 동반되어야 할 것이 다. 따라서 주기적인 안정성 모니터링을 통해 세병관 초 석의 내구성을 관리할 필요가 있으며, 이는 다양한 중요 대형건축문화재에도 적용되어야 할 것이다.

\section{5. 결 언}

1. 세병관(국보 제 305 호)은 통영의 삼도수군통제영에 있으며, 창건(1605년)부터 현재까지 수차례의 중건, 중수, 보수 및 복원을 거쳤다. 세병관에 사용한 초석은 총 50 개로 6종류의 암석으로 구성되어 있으며, 표면에서는 다 양한 손상이 나타난다.

2. 초석의 암석은 대부분 석영안산암질 래피리응 응회 암이며, 이를 이용해 세병관의 주요 위치에 초석을 배치 하였고 치석의 형태가 비교적 일정하다. 다른 암종은 주 로 좌측면과 배면 외곽에 분포하고 있으며, 섬록암과 유 문암은 가공과 설치특성으로 볼 때 근래에 보수한 신재
로 판단된다.

3. 세병관 원형 초석의 산지와 대체석 수급을 위해 모 든 암종별 암석을 세병관 반경 $2 \mathrm{~km}$ 안에서 수습하였다. 산지탐색 암석은 대부분의 초석과 산출상태, 기재적 및 광물학적 특징, 전암대자율 분포 등 암석학적으로 높은 동질성을 갖는 것으로 나타나 산지의 개연성은 충분히 입증되었으나, 향후 필요한 경우가 있다면 면밀한 재검 토가 있어야 할 것이다.

4. 초석에 대한 정량적 표면손상도 평가 결과, 가장 심 한 손상유형은 박리와 박락으로, 주로 외진주 초석에서 높은 점유율을 보이는 것으로 보아 응회암질 암석의 특 성 및 해풍과 노출상태 등 환경적 요인으로 인한 염 풍 화가 주요 원인으로 판단된다.

5. 전체적인 손상메커니즘으로 볼 때 초석의 갈색 및 흑색변색은 암석의 조암광물에서 기인한 것으로, 외부에 서는 $\mathrm{Na}$ 과 $\mathrm{Cl}$ 이 검출되는 것으로 보아 해풍에 의한 염 풍화를 겪는 것으로 판단된다. 한편 내부에서는 석고와 염화칼슘 등에 의한 화학적 풍화가 진행되어 외부와는 다른 복합적인 풍화메커니즘을 갖는 것으로 나타났다.

6. 초석의 기계적 내구성을 검토하기 위해 초음파 물성 진단을 수행한 결과, 현재 물성저하로 부재의 교체가 필 요한 초석은 없는 것으로 보이나, 대부분의 물성이 3 등 급의 풍화도를 보여 비교적 건전한 것으로 판단된다. 그 러나 표면의 손상을 늦추기 위한 보존처리가 필요할 것이다.

7. 세병관 초석은 상부가구를 지탱하는 기초로 강도에 대한 검토가 매우 중요하다. 초석의 내구성은 단순한 물 성진단이 아닌 구조물에 직간접적인 영향을 미치는 요인 으로 관리대상이다. 또한 초석에 발생한 물리적 손상과 내부 결함을 유발하는 손상메커니즘이 다소 복합적으로 작용하였다. 따라서 세병관의 장기적인 보존을 위해 주 기적인 상태점검과 모니터링이 요구된다.

\section{References}

Chang, T.W., Hwang, S.K., Lee, D.W., Oh, I.S., Kim, H.C. and Lim, E.H. (1983) Geological Report of the Chungmu Sheet (1:50,000). Korea Institute of Energy and Resources, 1-47. (in Korean with English abstract)

Cho, J.H. and Lee, C.H. (2020) Characteristics of salt weathering and environmental variation on the Usuki stone Buddha statues in Oita, Japan. Economic and Environmental Geology, v.53(6), p.677-685. (in Korean with English abstract) doi: 10.9719/ EEG.2020.53.6.677

Cho, J.H., Lee, C.H., Kim, J.Y., Morii, M., Lee, M.S. and Kim, S.D., (2012) Deterioration evaluation and material characteristics of the Usuki stone Buddha statues in Oita, Japan. Journal of Conservation Science, v.28, p.39-52. (in Korean with English 
abstract)

Govindaraju, K. (1989) 1989 Compilation of working values and samples description for 272 geostandards. Geostandards Newsletter, v.13, p.1-113. doi: 10.1111/j.1751-908X.1989.tb00476.x

Iliev, I.G. (1966) An attempt to estimate the degree of weathering of intrusive rocks from their physical-mechanical properties. Proceedings of the International congress on Rock Mechanics, v.1, p.109-114.

Jo, Y.H. and Lee, C.H. (2011) Making method of deterioration map and evaluation techniques of surface and three-dimensional deterioration rate for stone cultural heritage. Journal of Conservation Science, v.27(3), p.251-260. (in Korean with English abstract)

Jo, Y.H. and Lee, C.H. (2014a) Quantitative modeling of blistering zones by active thermography for deterioration evaluation of stone monuments. Journal of Cultural Heritage, v.15(6), p.621627. doi: 10.1016/j.culher.2013.12.002

Jo, Y.H. and Lee, C.H. (2014b) Establishment of ultrasonic measurement method for stone cultural heritage considering water content and anisotropy. Journal of Conservation Science, v.30, p.467-480. (in Korean with English abstract) doi: 10.12654/ JCS.2014.30.4.15

Jo, Y.H. and Lee, C.H. (2015) A study on selection of ultrasonic transducer and contact material for surface irregularities of stone cultural heritage. Journal of Conservation Science, v.31, p.267278. (in Korean with English abstract) doi: 10.12654/ JCS.2015.31.3.07

Kim, D.K. (2005) A measurment investigation report of Sebyeonggwan government office. Journal of Architectural History, v.14, p.200219. (in Korean with English abstract)

Lee, C.H., Kim, Y.T. and Lee, M.S. (2007) Provenance presumption for rock properties of the Five-storied stone pagoda in the Jeongrimsaji temple site, Buyeo, Korea. Journal of the Geological Society of Korea, v.43, p.183-196. (in Korean with English abstract)

Lee, C.H., Kim, M.Y., Jo, Y.H. and Lee, M.S. (2010) Conservation treatment based on material characteristics, provenance presumption and deterioration diagnosis of the Seven-storied Jungwon Tappyeongri stone pagoda, Chungju, Korea. Korean
Journal of Cultural Heritage Studies, v.43, p.4-25. (in Korean with English abstract) doi: 10.22755/kjchs.2010.43.3.4

Lee, C.H. and Jo, Y.H. (2017) Correlation and correction factor between direct and indirect methods for the ultrasonic measurement of stone samples. Environmental Earth Science, v.76, p.477-489. doi: 10.1007/s12665-017-6810-7

Lee, C.H., Jo, Y.H. and Chun, Y.G. (2009) Establishment of ultrasonic measurement and correlations of direct-indirect method for weathering evaluation of stone cultural heritage. Journal of Conservation Science, v.25, p.233-244. (in Korean with English abstract)

Le Maitre, R.W., Streckeisen, A., Zanettin, B., Le Bas, M.J., Bonin, B. and Bateman, P., 2002, Igneous Rocks: A Classification and Glossary of Terms. Cambridge University Press, 1-236.

Min, K,W., Chin, H.I. and Park, J.D. (2003) Deterioration of stone materials by salt weathering. Journal of Advanced Mineral Aggregate Composites, v.8, p.3-8. (in Korean with English abstract)

Nockolds, S.R. (1954) Average chemical compositions of some igneous rocks. Geological Society of American Bulletin, v.65, p.1007-1032. doi: 10.1130/0016-7606(1954)65[1007:ACCOSI] 2.0.CO;2

Park, J.H., Lee, G.H. and Lee, C.H., 2019, Consideration for historical application of augen gneiss and petrographic characteristics for rock properties of Donghachong tomb from royal tombs of Neungsanri in Buyeo, Korea. Economic and Environmental Geology, v.52(1), p.91-106. (in Korean with English abstract) doi: 10.9719/EEG.2019.52.1.91

Pearce, J.A. (1983) Role of sub-continental lithosphere in magma genesis at active continental margines. In Hawkesworth, C.J. and Norry, M.J. (eds.), Continental basalts and mantle xenolith, Shiva, p.230-249.

Taylor, S.R. and McLennan, S.M. (1985) The continental crust: Its composition and evolution. Blackwell, Oxford, p.312.

Uchida, E., Cunin, O., Suda, C., Ueno, A. and Nakagawa, T. (2007) Consideration on the construction process and the sandstone quarries during the Angkor period based on the magnetic susceptibility. Journal of Archaeological Science, v.34, p.924935. doi: 10.1016/j.jas.2006.09.015 